\title{
A systems analysis of the chemosensitivity of breast cancer cells to the polyamine analogue PG-I 047
}

Wen-Lin Kuo*1, Debopriya Das ${ }^{1}$, Safiyyah Ziyad1', Sanchita Bhattacharya ${ }^{1}$, William J Gibb1, Laura M Heiser ${ }^{1}$, Anguraj Sadanandam¹, Gerald V Fontenay ${ }^{1}$, Zhi Hu ${ }^{2}$, Nicholas J Wang1, Nora Bayani1, Heidi S Feiler ${ }^{1}$, Richard M Neve ${ }^{1}$, Andrew J Wyrobek ${ }^{1}$, Paul T Spellman ${ }^{1}$, Laurence J Marton ${ }^{3}$ and Joe W Gray ${ }^{1,2}$

Address: ${ }^{1}$ Life Sciences Division, Lawrence Berkeley National Laboratory, Berkeley, California, USA, ${ }^{2}$ Comprehensive Cancer Center, University of California, San Francisco, California, USA and ${ }^{3}$ Progen Pharmaceuticals, Redwood City, California, USA

Email: Wen-Lin Kuo* - wlkuo@lbl.gov; Debopriya Das - debodas@lbl.gov; Safiyyah Ziyad - fiazia@mac.com;

Sanchita Bhattacharya - sanchita@stanford.edu; William J Gibb - WJGibb@lbl.gov; Laura M Heiser - lmheiser@lbl.gov;

Anguraj Sadanandam - sadanangu@gmail.com; Gerald V Fontenay - GVFontenay@lbl.gov; Zhi Hu - zhu@lbl.gov;

Nicholas J Wang - njwang@lbl.gov; Nora Bayani - nbayani@lbl.gov; Heidi S Feiler - hsfeiler@lbl.gov;

Richard M Neve - neve.richard@gene.com; Andrew J Wyrobek - AJWyrobek@lbl.gov; Paul T Spellman - ptspellman@lbl.gov;

Laurence J Marton - laurencem@progen-pharma.com; Joe W Gray - jwgray@lbl.gov

* Corresponding author

Published: I4 December 2009

BMC Medicine 2009, 7:77 doi:10.1/86/1741-7015-7-77
Received: 17 November 2009

Accepted: I4 December 2009

This article is available from: http://www.biomedcentral.com/1741-70I5/7/77

(c) 2009 Kuo et al; licensee BioMed Central Ltd.

This is an Open Access article distributed under the terms of the Creative Commons Attribution License (http://creativecommons.org/licenses/by/2.0), which permits unrestricted use, distribution, and reproduction in any medium, provided the original work is properly cited.

\begin{abstract}
Background: Polyamines regulate important cellular functions and polyamine dysregulation frequently occurs in cancer. The objective of this study was to use a systems approach to study the relative effects of PG-I 1047, a polyamine analogue, across breast cancer cells derived from different patients and to identify genetic markers associated with differential cytotoxicity.

Methods: A panel of 48 breast cell lines that mirror many transcriptional and genomic features present in primary human breast tumours were used to study the antiproliferative activity of PG1 1 047. Sensitive cell lines were further examined for cell cycle distribution and apoptotic response. Cell line responses, quantified by the $\mathrm{Gl}_{50}$ (dose required for $50 \%$ relative growth inhibition) were correlated with the omic profiles of the cell lines to identify markers that predict response and cellular functions associated with drug sensitivity.

Results: The concentrations of PG-I I047 needed to inhibit growth of members of the panel of breast cell lines varied over a wide range, with basal-like cell lines being inhibited at lower concentrations than the luminal cell lines. Sensitive cell lines showed a significant decrease in $\mathrm{S}$ phase fraction at doses that produced little apoptosis. Correlation of the $\mathrm{Gl}_{50}$ values with the omic profiles of the cell lines identified genomic, transcriptional and proteomic variables associated with response.
\end{abstract}

Conclusions: A 13-gene transcriptional marker set was developed as a predictor of response to PG-II047 that warrants clinical evaluation. Analyses of the pathways, networks and genes associated with response to PG-II047 suggest that response may be influenced by interferon signalling and differential inhibition of aspects of motility and epithelial to mesenchymal transition.

See the related commentary by Benes and Settleman: http://www.biomedcentral.com/I74I-7015/ $\underline{7 / 78}$ 


\section{Background}

Low molecular weight polycationic polyamines are found in cells in millimolar concentrations and are essential for mammalian cell proliferation, survival and function [1]. Polyamines are associated with nucleic acid metabolism, maintenance of chromatin structure, regulation of specific gene expression, ion channel modulation and membrane stability [1]. The synthesis and catabolism of the polyamines is exquisitely regulated. Polyamines and their biosynthetic enzymes are co-ordinately regulated with growth controls, and polyamine dysregulation frequently occurs in cancer [2]. Thus, targeting this pathway may provide therapeutic advantage in cancer and other hyperproliferative diseases. The polyamine pathway is a downstream target of known oncogenes and the inhibition of polyamine synthesis disrupts the action of these genes [2]. It also appears that the polyamines are critical to the activity of a number of histone deacetylase inhibitors [3]. Thus, the polyamine pathway is a site of therapeutic intervention that is common to, and distal to, a number of validated targets and drugs that interfere with polyamine metabolism and function should have utility both alone and in combination with other agents.

Several approaches to modulating the polyamine pathway have been utilized to date [2]. Targeting the key biosynthetic enzymes has yielded important scientific tools and some clinical success. Difluoromethylornithine, an inhibitor of the first enzyme in the mammalian polyamine biosynthetic pathway, ornithine decarboxylase, is approved for use in trypanosomiasis and has shown promise in the therapy of brain tumours [4]. It has also displayed excellent activity as a chemoprevention for colon polyps, when used in combination with sulindac [5]. However, enzyme inhibitors of the polyamine pathway have generally had limited clinical success to date. A second approach uses dysfunctional synthetic polyamine analogues to competitively inhibit natural polyamine functions. Many of the analogues synthesized to date take advantage of the self-regulatory properties of the natural polyamines and significantly modulate the activity of the biosynthetic and catabolic enzymes, lowering endogenous polyamine levels. Additionally, some of these compounds may function as polyamine mimetics, binding to normal polyamine binding sites in the cell to attenuate normal functions [6].

The compound utilized in this study, PG-11047, is a second generation polyamine analogue of $N^{1}, N^{12}$-bisethylspermine (BESpm) [7]. PG-11047 is a conformationally restricted analogue of BESpm with a cis double bond between the central carbons. It is thought to inhibit proliferation and other cellular functions by competing with natural polyamines. It is active against human cancer cells both in vitro [7] and in mouse xenografts [8]. It has shown positive results in the treatment of lymphoma in a phase I human clinical trial as well as in a phase II study for prostate cancer. It has thus far displayed a very benign toxicity profile and a phase I monotherapy trial is nearing completion [2]. It is also in a phase $1 \mathrm{~b}$ trial in combination with each of seven different approved drugs (Clinical Trial Identifier: NCT00705874). For the combination of PG11047 with docetaxel or gemcitabine maximally tolerated doses have been reached. Dose escalation of PG-11047 in combination with either bevacizumab, erlotinib, cisplatin, 5-fluorouracil or sunitinib malate is ongoing. With phase II trials emerging as the next step in the evaluation of the efficacy of PG-11047, specific pre-clinical studies are being undertaken to help guide the choice of appropriate clinical subjects. Such preclinical studies include extensive in vitro screens in order to provide an insight into the subpopulations of specific cancer types that might be amenable to treatment with PG-11047, while at the same time identifying putative molecular markers for the prediction of sensitivity or resistance to treatment.

Breast cancers develop through multiple genetic and epigenetic changes resulting in a wide range of cancer phenotypes. The resulting breast cancers have been classified, based on their gene expression profiles, into five distinct subtypes that are associated with diverse tumour characteristics and clinical outcome $[9,10]$ and into three groups based on their genomic characteristics [11]. Treatment of a limited number of human breast cancer cell lines in culture with PG-11047 has been reported to inhibit cell growth and/or induce cell death $[12,13]$. To better delineate the response of breast cancer cells to PG-11047, we studied the antiproliferative activity of this drug in a panel of 48 breast cell lines (including six non-malignant breast cell lines) that mirror many transcriptional and genomic features present in primary human breast tumours [14]. The initial characterization of this panel shows that the cell lines are comprised of three subtypes designated basal A, basal B and luminal. The basal A subtype corresponds most closely to tumours designated as basal-like $[15,16]$ by expression profiling while the basal B subtype corresponds most closely to tumours designated as claudinlow [17] (and Spellman et al., personal communication). The basal A and basal B subtypes will be referred to as basal and claudin-low, respectively, in the following text. Our studies show that basal subtype breast cancer cell lines are most sensitive to treatment with PG-11047 based on the dose required to inhibit $50 \%$ relative growth $\left(\mathrm{GI}_{50}\right)$. Correlations between cell line responses quantified by the $\mathrm{GI}_{50}$ and the transcriptional and genomic characteristics of these cell lines identified a set of 250 genes that are associated with response. A signature comprised of 13 of these genes is proposed as a predictor of response to PG-11047 treatment in breast tumours. 


\section{Methods}

\section{Breast cancer cell lines}

Breast cancer cell lines were obtained from the American Type Culture Collection and from collections developed in the laboratories of Drs Steve Ethier (Karmanos Cancer Center, MI, USA) and Adi Gazdar (UT Southwestern Medical Center, TX, USA). Forty of the cell lines were characterized in great detail by Neve et al. [14], eight were acquired recently and characterized in similar fashion for subtype classification (Spellman et al., personal communication). The recurrent genome copy number abnormalities in the collection of cell lines was similar to those in primary tumours, while hierarchical analysis of the transcriptional features of the cell lines defined three clusters designated luminal, basal and claudin-low [14].

\section{Cell growth inhibition assay and data analysis}

Cells were plated at proper density (from 1000 to 15,000 cells/100 $\mu \mathrm{l} /$ well, depending on the cell line) in 96-well plates, so that they remained in logarithmic growth at the time of assay. The cells were allowed to attach overnight before being exposed to the polyamine analogue PG11047 for 72 h. PG-11047 ( $N^{1}, \quad N^{12}$ bis(ethyl)-6,7dehydrospermine tetrahydrochloride, previously known as SL-11047 and CGC-11047) was obtained from Progen Pharmaceuticals (CA, USA) and a stock solution of 100 $\mathrm{mM}$ was prepared in sterile water. For the dose response study, a set of nine doses (final concentration from $5 \mathrm{mM}$ to $13 \mathrm{nM}$ ) in 1:5 serial dilution were added in triplicate wells. Adenosine triphosphate content was measured as an estimate of relative cell number using the CellTiter-Glo (CTG) Luminescent Cell Viability Assay (Promega, WI, USA), with slight modification form manufacturer's protocol, at day 0 (time when drug was added) and day 3 of drug exposure. Briefly, the CTG reagent was diluted with phosphate-buffered saline (PBS; 1:1, volume: volume) and the culture media was removed from the 96-well plate prior to adding $50 \mu \mathrm{l}$ per well of the diluted CTG reagent. Luminescence from the assay was recorded using BIO-TEK FLx800.

Metrics describing the drug effects were calculated according to the methods described by the NCI/NIH DTP Human Tumor Cell Line Screen [18] and by Monks et al. [19]. The \% growth curve is calculated as $\left(\left(\mathrm{T}-\mathrm{T}_{0}\right) /\left(\mathrm{C}-\mathrm{T}_{0}\right)\right)$ $\times 100$, where $\mathrm{T}_{0}$ is the CTG luminescence at day $0, \mathrm{C}$ is the untreated control CTG luminescence at day 3 and $\mathrm{T}$ is the CTG luminescence at the test concentration. The dose response curve was fitted with GraphPad Prism4 software (GraphPad Software, Inc, CA, USA). The $\mathrm{GI}_{50}$ and TGI (total growth inhibition) values were determined as the drug concentrations that caused $50 \%$ and $0 \%$ relative growth at $72 \mathrm{~h}$ drug exposure, respectively.

\section{Bromodeoxyuridine (BrdUrd) labelling and cell cycle analyses}

The fractions of cells in the G1-S and G2 M phases of the cell cycle were estimated from measurements of BrdUrdDNA distributions [20]. For this, cells were set up the same as in the cell growth inhibition assay and treated with PG-11047 at three different doses of $0.3,10$ or 300 $\mu \mathrm{M}$ for $48 \mathrm{~h}$ and $72 \mathrm{~h}$. A positive control of $10 \mathrm{nM}$ docetaxel treatment was included in all experiments. Cells were pulse labelled with a final BrdUrd concentration of $10 \mu \mathrm{M}$ for $30 \mathrm{~min}$, then fixed with $70 \%$ ethanol overnight in the 96-well plate. Fixed cells were denatured with $2 \mathrm{~N}$ hydrochloric acid for $30 \mathrm{~min}$ and then incubated with primary anti-BrdUrd antibody (BD Biosciences, CA, USA; 1:100 dilutions), followed by staining with a secondary antibody (1:500 dilution) labelled with Alexa-488 and counterstained with Hoechst 33342 (1:2000 dilution). The cells were then placed in PBS and Hoechst 33342 and Alexa-488 images were acquired for cells in each well using an ArrayScan imaging system (Cellomics Inc, PA, USA). The Hoechst images were segmented to localize nuclei and Hoechst fluorescence was measured for each nucleus as an estimate of relative DNA content. Alexa-488 fluorescence was measured for each segmented nucleus as an estimate of incorporated BrdUrd. Several thousand cells were measured for each well and the Hoechst 33342 and Alexa-488 results were combined to produce a bivariate BrdUrd-DNA distribution similar to that produced using flow cytometry [20]. The bivariate distributions for each well were analysed to determine the fractions of cells in the G1, S and G2 M phases of the cell cycle using FlowJo software (Tree Star, Inc, OR, USA). Flow cytometric BrdUrd-DNA distributions measured for several replicate experiments produced cell cycle fractions similar to those obtained using the imaging approach (data not shown).

\section{Apoptosis assay}

The extent of PG-11047-induced apoptosis was determined using the Caspase-Glo 3/7 assay kit from Promega (WI, USA). A positive control of $10 \mathrm{nM}$ docetaxel treatment was included in all experiments. After incubation of cells with PG-11047 at the specified concentrations for 48 h or 72 h, $50 \mu$ l Caspase-Glo reagent was added to wells. After an incubation time of $1 \mathrm{~h}$, luminescence was measured using a BIO-TEK FLx800 luminometer. Parallel experiments were set up to determine the relative number of viable cells using the CTG assay, as described above, in order to normalize the caspase activity by relative cell density.

\section{Statistical analysis of molecular markers associated with response}

The PG-11047 GI $_{50}$ levels for all cell lines were correlated with the molecular features measured for each cell lines 
(microarray profiles for RNA expression and genome copy number and Western blot based protein profiles) as reported by Neve et al. [14]. We used a statistical approach based on adaptive linear splines in order to identify the molecular correlates of response to PG-11047. These are variants of the linear splines method described previously [21]. Briefly, we used a non-parametric regression method to model non-linear relationships between molecular correlates and response. The goodness of fit was assessed by evaluating a $P$-value corresponding to the $F$-statistic for the fit [21]. $P$-values were corrected for multiple hypotheses testing using the false discovery rate method [22]. This process identified 250 genes whose transcripts were associated with response. From these, a 13 gene set was developed in order to predict a quantitative response among the cell lines using Monte Carlo cross-validation (MCCV) [23]. The complete panel of cell lines was used for this purpose. In MCCV, the samples (cell lines) are randomly partitioned into training sets and test sets. The marker genes found to be significant in the training set are then evaluated for their predictive accuracy in the test set. This random partitioning process is iterated multiple times. The 13 genes were consistently found to be significant across the iterations. More details are described in [23] (also, Das et al, in preparation). The final model was determined via leave-one-out cross-validation. Ingenuity Pathway Analysis (IPA 5.0; Ingenuity Software, Inc, CA, USA) knowledgebase molecular interactome was applied to the 250 predictor genes to identify the networks of genes, generated algorithmically based on their connectivity. Network genes were further analysed for significant pathways associations.

\section{Results \\ Effect of polyamine analogue PG-I I 047 on breast cancer cell lines}

Forty-two breast cancer cell lines representing luminal, basal and claudin-low breast cancer subtypes and six nonmalignant breast cell lines were treated with PG-11047 in doses ranging from $13 \mathrm{nM}$ to $5 \mathrm{mM}$ for $72 \mathrm{~h}$. The $\mathrm{GI}_{50}$ dose was calculated for each of the cell lines and ranged from $0.4 \mu \mathrm{M}$ to $5 \mathrm{mM}$ (Additional File 1 ) with a median $\mathrm{GI}_{50}$ at $31.5 \mu \mathrm{M}$. The distribution of $\mathrm{GI}_{50}$ values for the cell lines arranged from most sensitive to most resistant is shown in Figure 1 along with subtype classification. These data show that the basal and claudin-low subtypes were inhibited at the lowest levels of PG-11047 $(P<0.01$; MannWhitney test). The TGI (dose required to inhibit 100 percent of the cell growth from $\mathrm{T}_{0}$ ) showed similar subtype specificity (Additional File 1).

\section{Predictive markers for PG-I 1047 response}

We correlated the $\mathrm{GI}_{50}$ values for the cell lines in the panel with their pretreatment genomic, transcriptional and proteomic profiles in order to identify molecular factors associated with cellular response to PG-11047. Additional Files 2, 3 and 4 list mRNA, DNA and protein features that were significantly associated with response. The molecular features associated with response or resistance when present at elevated levels are listed as response predictors.

IPA of 250 mRNA transcripts significantly associated with response showed several pathways as significantly associated with response (Table 1). The interferon signalling pathway was most significantly involved in PG-11047 response, with four of the genes identified in the top 250

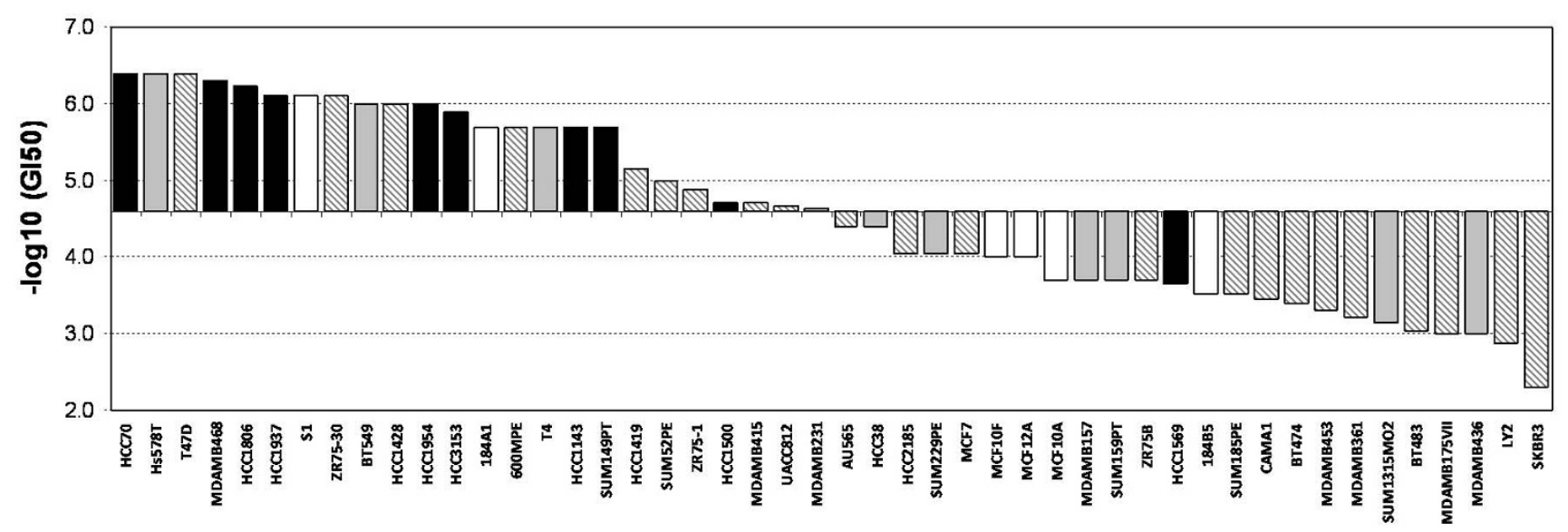

Figure I

Growth inhibition $\left(\mathbf{G I}_{\mathbf{5 0}}\right)$ sensitivity profile of the breast cell lines to PG-I I 047. Cell lines are arranged from sensitive (left) to resistant (right) based on median centred $\mathrm{GI}_{50}$ value. Solid bar, basal; gray bar, claudin low; striped bar, luminal subtype; white bar, non-malignant breast cells. 
Table I: Significant pathways from top 250 predictor genes associated with response to PG-I I 047 treatment using Ingenuity Pathway analysis.

\begin{tabular}{|c|c|c|c|}
\hline Pathway Name & P-Value & Ratio & Component genes in the pathway \\
\hline Interferon Signaling & 0.001 & {$[4 / 29]$} & IRFI, IRF9, TAPI, IFNGRI \\
\hline Ephrin Receptor Signaling & 0.011 & $\begin{array}{l}{[8 /} \\
193]\end{array}$ & $\begin{array}{l}\text { CXCR4, ABII, RAPIA, MAPKI, WASL, } \\
\text { MAP4K4, GNAI3, PAKI }\end{array}$ \\
\hline $\begin{array}{l}\text { Role of BRCAI in DNA Damage } \\
\text { Response }\end{array}$ & 0.013 & {$[4 / 52]$} & RPAI, RFC3, MSH2, E2F3 \\
\hline $\begin{array}{l}\text { Nicotinate and Nicotinamide } \\
\text { Metabolism }\end{array}$ & 0.019 & $\begin{array}{l}{[5 /} \\
129]\end{array}$ & NNMT, ENPP2, MAPKI, ENPPI, PAKI \\
\hline $\begin{array}{l}\text { Fcy Receptor -mediatedPhagocytosis in Macrophages } \\
\text { andMonocytes }\end{array}$ & 0.028 & $\begin{array}{l}{[5 /} \\
104]\end{array}$ & RPS6KBI, LYN, MAPKI, VAMP3, PAKI \\
\hline Riboflavin Metabolism & 0.032 & {$[2 / 49]$} & ENPP2, ENPPI \\
\hline $\begin{array}{l}\text { Endoplasmic Reticulum Stress } \\
\text { Pathway }\end{array}$ & 0.041 & {$[2 / 18]$} & XBPI, TAOK3 \\
\hline Pantothenateand CoA Biosynthesis & 0.046 & {$[2 / 63]$} & ENPP2, ENPPI \\
\hline CXCR4 Signaling & 0.052 & $\begin{array}{l}{[6 /} \\
164]\end{array}$ & CXCR4, RHOB, LYN, MAPKI, GNAI3, PAKI \\
\hline PI3K/AKT Signaling & 0.055 & $\begin{array}{l}{[5 /} \\
135]\end{array}$ & RPS6KBI, SFN, MAPKI, YWHAH, PPP2R5A \\
\hline Integrin Signaling & 0.056 & $\begin{array}{l}{[7 /} \\
198]\end{array}$ & RHOB, RAPIA, MAPKI, TSPAN6, WASL, ARF4, PAKI \\
\hline
\end{tabular}

Ratio indicates the number of genes in the top 250 predictors that belong to the pathway indicated over the number of genes known of the pathway. Genes in bold were associated with resistance when transcribed at high levels. Genes in normal fonts were associated with sensitivity when transcribed at high levels.

genes out of a total of 29 genes identified in the pathway. Network connectivity analysis suggested interactions among the 250 genes most significantly associated with response. The most significant two networks are shown in Figure 2. Network 1 involves basal cytokeratins, ubiquitin/proteasome processes, RNA processing and histone deacetylase. Network 2 involves interferon signalling.

Further analysis of the 250 mRNA transcript levels associated with response in the cell lines yielded a 13 gene signature as possible clinical predictor of response to PG11047 treatment (Table 2). Higher levels of expression of WASL, CST3, DEAF1 and ACSL3 were associated with resistance to PG-11047 while high expression levels of GCLM, LAMA3, SSRP1, ACYP1, CYLD, PRPF18, AMFR, PPP1R2 and LOH11CR2A were associated with increased sensitivity. We evaluated the performance of the 13 gene signature in predicting sensitivity of the cell-lines to PG11047. The average correlation between predicted and measured sensitivities was 0.93 . Here, multiple random samplings of training and test sets were performed. The average reflects the performance of the predictive model across these iterations in the test sets. The genes in this signature are involved in cell motility, response to stress and cellular metabolic processes, based on the known functions of the genes.

Correlative analysis of $\mathrm{GI}_{50}$ sensitivity of the cell line panel with genomic copy number aberration (array comparative genomic hybridization data) and protein level (Western data) identified additional markers significantly associated with response. These are listed in Additional Files 3 and 4 . Several of the 13 gene signature transcriptional markers were found in regions of genomic abnormality associated with response. Examples include: genomic copy gains of the chromosomal regions near AMFR (16q21), SSRP1 (11q12) and LOH11CR2A (11q23) and copy number loss of CST3 (20p11.2) that predict sensitiv- 


\section{Network 1}

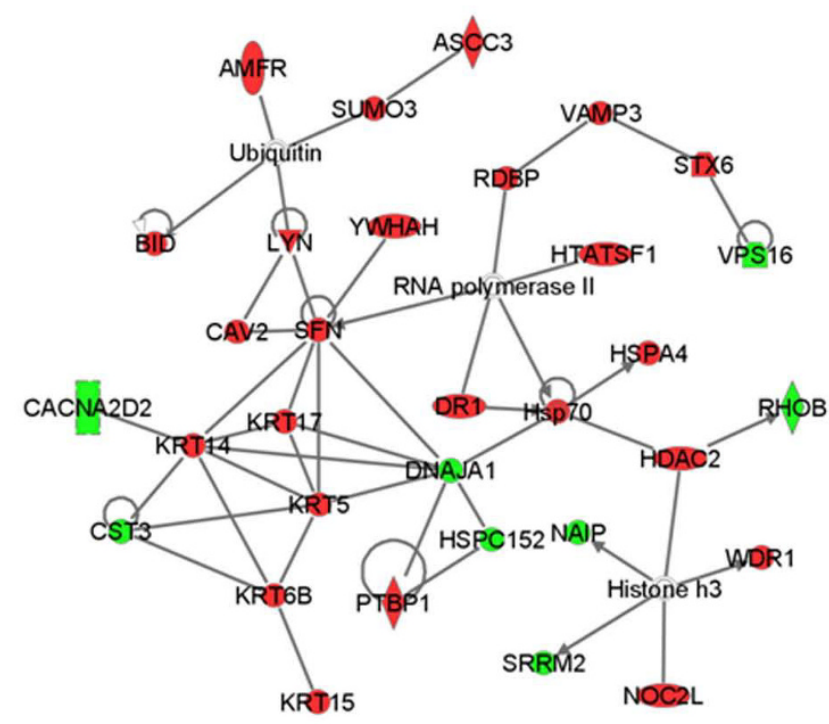

\section{Network 2}

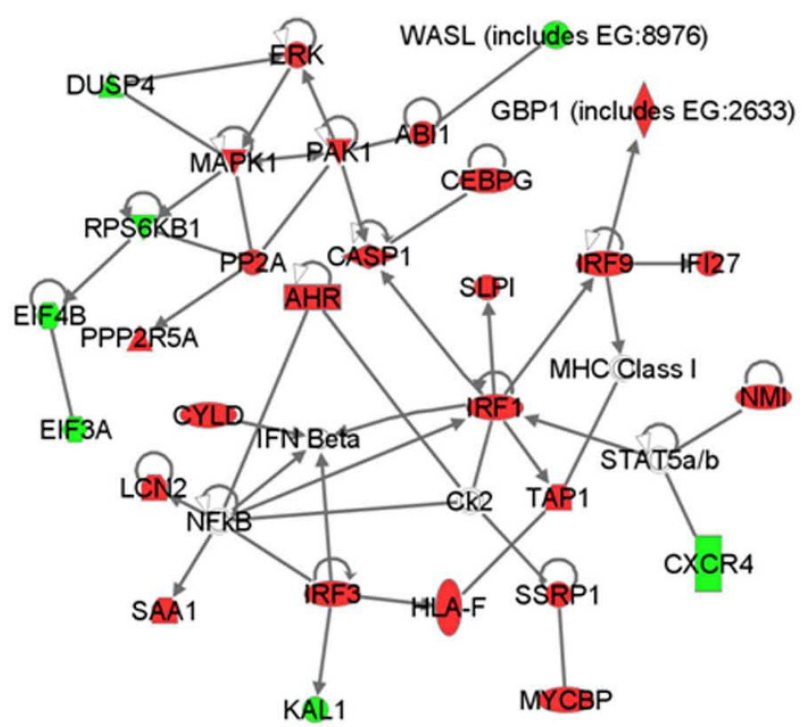

\section{Figure 2}

Network analysis of the top $\mathbf{2 5 0}$ predictor genes. Ingenuity Pathway Analysis was applied to the top 250 predictor genes to identify gene networks based on connectivity (red: predictor of sensitivity, green: predictor of resistance). The top two networks are shown here. The network scores for networks I and 2 are 54 and 49, respectively. Nodes are displayed using shapes that represent the functional class of the gene product. Edges are displayed with labels that describe the nature of the relationship between the nodes. All edges are supported by at least I reference from the literature, or from canonical information stored in the Ingenuity Pathways Knowledge Base.

ity to PG-11047 treatment (Additional File 3). These observations are consistent with the predictors developed with the mRNA expression data and suggest that genomic aberrations may drive the changes in gene expression that determine response to PG-11047. Interestingly, the status of AKT was among the protein levels significantly associated with response (Additional file 4), with high phospho-AKT associated with sensitivity and high AKT associated with resistance. Not surprisingly, high level expression of the basal subtype cytokeratins, CK5 and CK6, were associated with sensitivity while high level expression of the luminal cytokeratin, CK18 was associated with resistance.

\section{PG-I 047 mediated cell cycle changes}

We examined the effect of PG-11047 on cell cycle distribution and apoptosis in order to understand the mechanism by which PG-11047-induced growth inhibition occurred. Six sensitive and three resistant cell lines were plated and treated as stated previously. These were labelled with BrdUrd at 48 and $72 \mathrm{~h}$ after PG-11047 treatment. The sensitive cell lines showed a greater reduction in fraction of cells incorporating BrdUrd than did the resistant cells. The cell cycle distributions of these cell lines treated with $0.3,10$ and $300 \mu \mathrm{M}$ of PG-11047 for 72 $\mathrm{h}$ are shown in Figure 3A. There was a significant decrease in the fraction of cells in S-phase with increasing doses of PG-11047 in the cell lines that showed highest sensitivity; this effect was clearer at $72 \mathrm{~h}$ than at $48 \mathrm{~h}$ of exposure (data not shown). The three resistant cell lines, MDAMB436, MDAMB361 and SKBR3, showed only modest changes in the fractions of cells in S-phase. Apoptosis, measured with the Promega Caspase-Glo 3/7 assay, generally was induced at higher concentrations of PG-11047 than required to inhibit cell cycle traverse (Figure $3 \mathrm{~B}$ ) in sensitive cell lines. These data suggest that the growth inhibition induced by PG-11047 in these cell lines occurs more through cell cycle inhibition than by induction of apoptosis.

\section{Discussion}

Polyamines are required for cellular viability and elevated levels are found in many tumour types, including breast cancer [2], making polyamine synthesis an attractive target for chemotherapy. PG-11047 is a second generation polyamine analogue specifically designed as a therapeutic agent [7]. While it is reported to effectively inhibit cell growth in lung, breast and colon cancer cell lines 
Table 2: Gene list predicting sensitivity (S) or resistance (R) to PG-I I 047 treatment.

\begin{tabular}{|c|c|c|c|c|c|c|}
\hline Gene symbol & $P$-value & Predict & $\begin{array}{l}\text { Chromosome } \\
\text { location }\end{array}$ & Gene name & Function & References \\
\hline WASL & $2.5 \mathrm{E}-05$ & $\mathrm{R}$ & chr7q31.3 & Wiskott-Aldrich syndrome-like & $\begin{array}{l}\text { Key regulator of cell migration and } \\
\text { actin polymerization by interaction } \\
\text { with Ap2/3 complex }\end{array}$ & {$[32,47]$} \\
\hline GCLM & 4.7E-05 & $S$ & chrlp22.I & $\begin{array}{l}\text { Glutamate-cysteine ligase, } \\
\text { modifier subunit }\end{array}$ & $\begin{array}{l}\text { Regulatory subunit of glutamate- } \\
\text { cystein ligase, a rate-limiting enzyme } \\
\text { catalyzing the first step of GSK } \\
\text { biosynthesis from cysteine }\end{array}$ & [39] \\
\hline CST3 & $6.3 \mathrm{E}-05$ & $\mathrm{R}$ & chr20p II.2I & $\begin{array}{l}\text { Cystatin C (amyloid angiopathy } \\
\text { and cerebral haemorrhage) }\end{array}$ & $\begin{array}{l}\text { Potent inhibitor of lysosomal } \\
\text { proteinases. TGF } \beta \text { receptor } \\
\text { antagonist, inhibit epithelial- } \\
\text { mesenchymal transition and } \\
\text { morphological transformation }\end{array}$ & {$[30]$} \\
\hline LAMA3 & 6.7E-05 & S & $\operatorname{chr}|8 q| 1.2$ & Laminin, alpha 3 & $\begin{array}{l}\text { Component of laminin } 5 \text {, the major } \\
\text { extracellular metrix protein produced } \\
\text { in the basement membrane of the } \\
\text { mammary epithelial cells. Induces } \\
\text { motility, invasion and epithelial- } \\
\text { mesenchymal transition }\end{array}$ & {$[35,48]$} \\
\hline SSRPI & I.2E-04 & S & $\operatorname{chrl}|q| 2$ & $\begin{array}{l}\text { Structure specific recognition } \\
\text { protein I }\end{array}$ & $\begin{array}{l}\text { Histone chaperone. Forms a } \\
\text { heterodimer with Spt } 16 \text { and is a } \\
\text { component of the chromatin } \\
\text { transcript regulation factor, FACT }\end{array}$ & {$[40,42]$} \\
\hline ACYPI & I.2E-04 & S & $\operatorname{chrl} 4 \mathrm{q} 24.3$ & $\begin{array}{l}\text { Acylphosphatase I, erythrocyte } \\
\text { (common) type }\end{array}$ & $\begin{array}{l}\text { Catalyze the hydroolysis of } \\
\text { acylphosphates }\end{array}$ & [49] \\
\hline CYLD & $2.9 \mathrm{E}-04$ & $S$ & $\operatorname{chr}|6 q| 2.1$ & $\begin{array}{l}\text { Cylindromatosis } \\
\text { (turban tumour syndrome) }\end{array}$ & $\begin{array}{l}\text { A deubiquinating enzyme that } \\
\text { negatively regulate the activity of } \\
\text { NFkB and JNK. Regulate mitotic entry }\end{array}$ & {$[43,45]$} \\
\hline PRPFI8 & $3.0 \mathrm{E}-04$ & $S$ & chrl0p/3 & $\begin{array}{l}\text { PRPI8 pre-mRNA processing } \\
\text { factor } 18 \text { homolog } \\
\text { (Saccharomyces cerevisiae) }\end{array}$ & $\begin{array}{l}\text { Participate in pre-mRNA splicing, } \\
\text { prepare mRNA for translation }\end{array}$ & {$[41]$} \\
\hline AMFR & 3.IE-04 & S & $\operatorname{chrl6q21}$ & $\begin{array}{l}\text { Autocrine motility factor } \\
\text { receptor }\end{array}$ & $\begin{array}{l}\text { Receptor for AMF, a tumour motility- } \\
\text { stimulating protein secreted by } \\
\text { tumour cells. Stimulation of AMFR by } \\
\text { AMF alters cellular adhesion, } \\
\text { proliferation, motility and apoptosis }\end{array}$ & {$[33,36]$} \\
\hline DEAFI & $7.9 \mathrm{E}-04$ & $\mathrm{R}$ & chrllpI5.5 & $\begin{array}{l}\text { Deformed epidermal } \\
\text { autoregulatory factor I } \\
\text { (Drosophila) }\end{array}$ & $\begin{array}{l}\text { A sequence-specific DNA-binding } \\
\text { protein required for development. } \\
\text { May be a general regulator of gene } \\
\text { transcription/expression. DEAFI (also } \\
\text { called 'suppressin') appear to be } \\
\text { mutated in tumours and cell lines }\end{array}$ & {$[50,51]$} \\
\hline PPPIR2 & $1.5 \mathrm{E}-03$ & S & chr3q29 & $\begin{array}{l}\text { Protein phosphatase I, } \\
\text { regulatory (inhibitor) subunit } 2\end{array}$ & $\begin{array}{l}\text { Inhibitor of protein phosphatase I. } \\
\text { Phosphorylation of PPPIR2 by } \\
\text { glycogen synthase kinase-3 (GSK3) } \\
\text { activates the enzyme. PPPIR2 (INH2) } \\
\text { regulates PPI complexed with NEK2 } \\
\text { to induce centrosome separation }\end{array}$ & [44] \\
\hline
\end{tabular}


Table 2: Gene list predicting sensitivity (S) or resistance (R) to PG-I 1047 treatment. (Continued)

\begin{tabular}{cccccc}
\hline LOHIICR2A & I.7E-03 & S & chrl Iq23 & $\begin{array}{l}\text { Loss of heterozygosity, II, } \\
\text { chromosomal region 2, gene A }\end{array}$ & $\begin{array}{l}\text { Frequent loss of heterozygosity at } \\
\text { IIq23 region found in many tumour } \\
\text { types }\end{array}$ \\
\hline ACSL3 & $1.8 \mathrm{E}-03$ & $\mathrm{R}$ & chr2q34-q35 & $\begin{array}{l}\text { Acyl-CoA synthetase long-chain } \\
\text { family member 3 }\end{array}$ & $\begin{array}{l}\text { Essential for fatty acid metabolism, } \\
\text { providing activated intermediates for } \\
\text { complex lipid synthesis, protein } \\
\text { modification, and beta oxidation }\end{array}$ \\
\hline
\end{tabular}

$[7,12,24]$, only a limited number of cell lines had previously been studied. Since breast cancer is now known to be comprised of multiple genomic and transcriptional subsets $[10,14]$ that progress and respond to therapy differently, we analysed quantitative responses to PG-11047 in a collection of 42 breast cancer and six non-malignant breast cell lines in order to identify biological and molecular features associated with response. Figure 1 shows that the basal subtype is most strongly inhibited by treatment with PG-11047, based on $\mathrm{GI}_{50}$ response profiles. Basal subtype breast cell lines mirror many molecular features of basal-like primary breast tumours $[15,16]$ including low expression of oestrogen receptor and ERBB2 and high expression of keratin 5/6/14 and EGFR (Spellman et al., personal communication). This suggests that, PG-11047 may be preferentially effective against this more aggressive breast cancer subtype. This is consistent with observations made in a study of the polyamine analogue, $N^{1}, N^{11}$ diethylnorspermine (DENSPM) [25]. An analysis of BrdUrd incorporation and apoptosis induction in sensitive and resistant cell lines suggests that responses to micromolar concentrations of PG-11047 mainly involve reduced cell cycle traverse rather than induction of apoptosis. Holst et al. [13] also reported inhibition of growth in the breast cancer cell lines with PG-11047, although they observed a stronger apoptotic response. This discrepancy might be explained by differences in assay conditions, since they assessed apoptosis as an increase in the
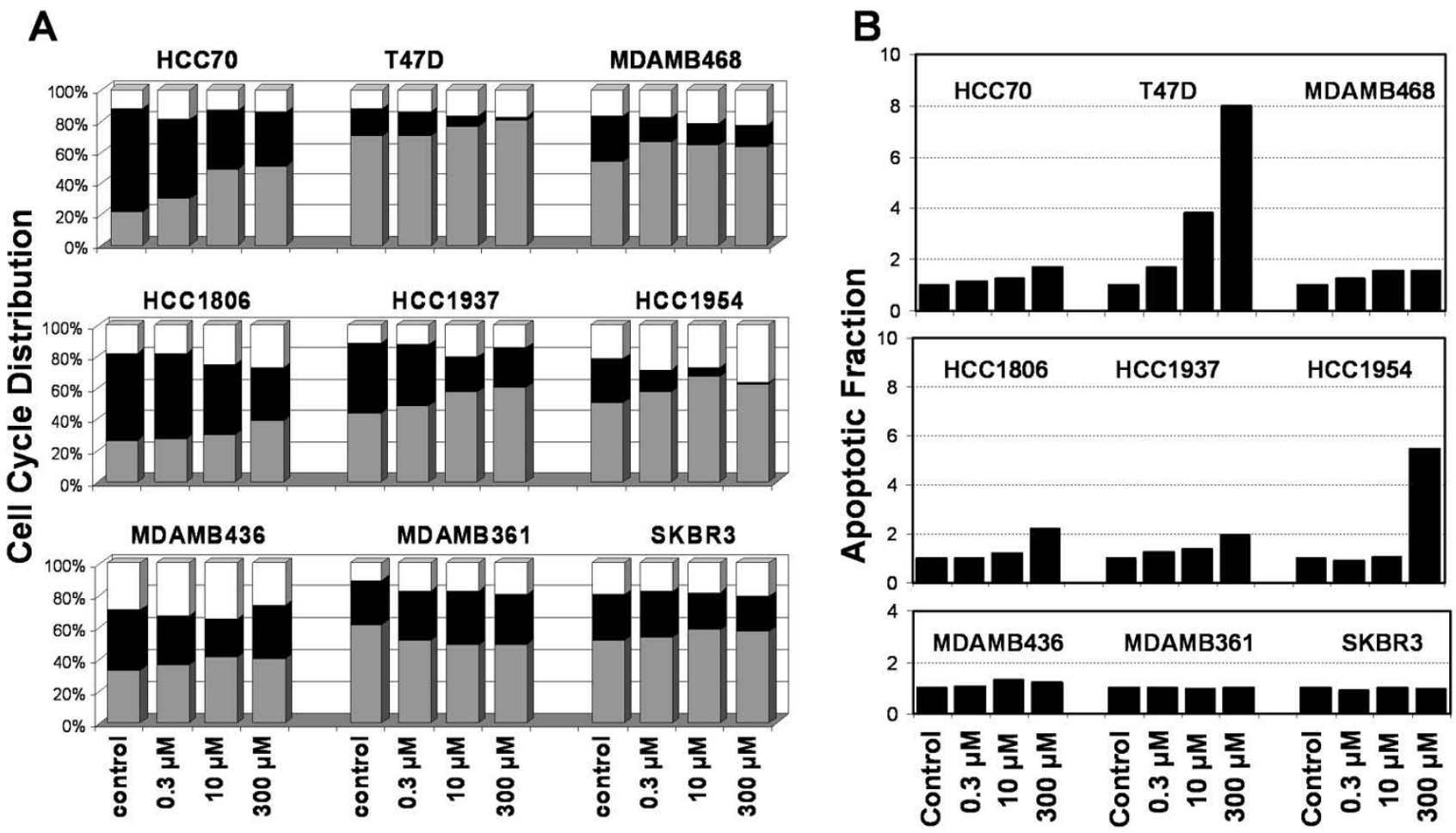

Figure 3

Cell cycle distribution and apoptotic fraction of PG-I 1047 treated breast cancer cell lines. Six sensitive (top two rows) and three resistant (bottom row) cell lines were tested with PG-I 1047 for $72 \mathrm{~h}$. (A) Fractions of cells estimated to be in the GI (gray bar), S (black bar) and G2/M (white bar) phases of the cell cycle. (B) Corresponding relative apoptotic activity normalized to untreated control relative cell number. 
fraction of cells showing sub-G1 DNA content, while our study was based on analysis of apoptosis related caspases

The concentration of drug needed to inhibit growth measured as $\mathrm{GI}_{50}$ or TGI ranged over four orders of magnitude which meant that molecular features associated with response could be identified with confidence. The correlation of transcription profiles of the cell lines with their $\mathrm{GI}_{50}$ sensitivity identified 250 genes whose expression levels were associated with response to PG-11047. Network and pathway analyses of these genes are summarized in Figure 2 and Table 1 . Increased interferon signaling was implicated with increased sensitivity to PG-11047 by both pathway and network analyses (Network 2). This is consistent with the observation that interferon inhibits the activity of ornithine decarboxylase (ODC) [26]. We speculate that cells with high interferon activity are preferentially sensitive to PG-11047 because interferon-induced down regulation of ODC reduces the endogenous pool of the polyamines with which PG-11047 must compete to affect its inhibitory functions. Other signalling pathways and networks implicated in Table 1 and Figure 2 have been reported to be differentially active in basal and luminal tumours and cell lines. For example, pathway activities associated with basal subtype tumours involve Ephrin receptor [14,27], BRCA1 [28] and integrins [29]. The strong basal subtype specificity of PG-11047 probably explains the associations with these pathway activities. Differential sensitivity of basal and luminal cells to PG11047 also probably explains the structure of Network 1 in Figure 2, since this network included several genes with strong subtype specific expression [14].

A further analysis of the 250 genes associated with response to PG-11047 identified 13 genes whose levels were strongly and independently associated with response (Table 2). We propose that a clinical response predictor could be generated by assaying the levels of expression of these genes. To this end, we evaluated the applicability of the 13 gene set in stratifying breast tumour transcription datasets. We used the model to predict the sensitivities of the tumour samples in the Chin et al. [11] tumour panel (total $=118$ samples). We found that there is a tendency toward separation between the predicted sensitivities of basal versus non-basal tumours $(P=0.08)$. The stratification improved if we restricted the analysis to high confidence predictions of the model (89/118 samples): $P=$ 0.01 . This analysis supports the utility of PG-11047 in the treatment of basal-subtype tumours.

Assessments of the contributions of these 13 responseassociated-genes to breast cancer pathophysiology may provide insights into breast cancer responses to PG-11047 that were not directly tested in this study. Table 2 shows that increased sensitivity to PG-11047 is associated with lower expression of WASL, CST3, DEAF1 and ACSL3 and higher expression of GCLM, LAMA3, SSRP1, ACYP1, CYLD, PRPF18, AMFR, PPP1R2 and LOH11CR2A.

Several of these associations suggest that PG-11047 may act to inhibit aspects of migration/metastasis. For example, the protein encoded by CST3 is an antagonist of TGF$\beta$ signaling and has been shown to be significantly down regulated in many breast cancers [30]. Thus, PG-11047 may be preferentially effective in cells with active TGF- $\beta$ signaling, a phenotype that has been associated with aggressive cancer behavior including increased migration/ metastasis [31] Reduced expression of WASL and increased expression of AMFR also have been reported in breast cancer tissue $[32,33]$ and associated with cellular migration [33-35]. Increased AMFR expression also is associated with increased phospho-AKT levels in primary human breast cancers [36]. Consistent with this, we observed that a higher protein level of phospho-AKT is a significant predictor for PG-11047 sensitive cells (Additional File 4). The implication of PG-11047 as an inhibitor of motility/metastasis is further supported by the fact that aspects of motility are known to be regulated by polyamines [37]. The associations of gains of the chromosomal regions near AMFR (16q21) and loss near CST3 (20p11.2) suggests that the associations of gene expression changes with motility/metastasis and that response to PG-11047 may be driven by genomic abnormalities.

Gene function assessments also suggest that PG-11047 may moderate aspects of epithelial to mesenchymal transition that are associated with aggressive clinical behaviour. For example, Carpenter et al. [38] have recently shown that laminin 5 may contribute to increased tumour aggressiveness resulting from epithelial to mesenchymal transition (EMT) in breast tumours. Increased expression of LAMA3, a subunit of laminin 5, is associated with response to PG-11047 suggesting the possibility that tumours responding to the drug also may experience reduced EMT. Among the other genes associated with response, GCLM and SSRP1 have been implicated in stress response $[39,40]$, PRPF18 and SSRP1 are involved with transcription/translation [41,42], CYLD and PPP1R2 are involved with cell cycle regulation $[43,44]$ and CYLD and LOH11CR2A have been reported as anti-oncogene/ tumour suppressor genes $[45,46]$.

\section{Conclusions}

We assessed the quantitative responses of 48 breast cell lines to PG-11047 and demonstrated that there is a wide range of response to treatment. Our studies suggest that basal-subtype breast cancers are preferentially sensitive to the drug and that response at lower treatment concentrations is cytostatic rather than apoptotic. Analysis of molecular features associated with response suggests that PG-11047 may also reduce metastasis-related motility and suppress the EMT phenotype. We have generated a 13 
gene set response signature to identify tumours expected to respond best to PG-11047 that may be useful in the selection of patients for further evaluation of PG-11047.

\section{Abbreviations}

BESpm: bisethylspermine; BrdUrd: bromodeoxyuridine; CTG: CellTiter-Glo; GI: growth inhibition; EMT: epithelial to mesenchymal transition; IPA: Ingenuity Pathway Analysis; $\mathrm{GI}_{50}$ : 50\% GI; TGI: total growth inhibition; MCCV: Monte Carlo cross validation; ODC: ornithine decarboxylase; PBS: phosphate-buffered saline.

\section{Competing interests}

LJM is an employee of Progen Pharmaceuticals. This work was supported in part by grant from Progen Pharmaceuticals.

\section{Authors' contributions}

WK, RMN, JWG, LJM, ZH, NJW and HSF made substantial contributions to the conception and design of the study. WK, SZ and NB carried out the experiments and helped with the data acquisition. WK, SZ, DD, SB, PTS, WJB, $\mathrm{LMH}, \mathrm{AS}$ and GVF helped with analysis and interpretation of the data. WK, DD, SZ, AJW, PTS, LJM and JWG were involved in drafting or critically revising the manuscript for important intellectual content. All authors gave their final approval of the version to be published.

\section{Additional material}

\section{Additional file 1}

Growth inhibition response $\left(G_{50}, T G I\right)$ to $P G-11047$ and molecular features of breast cell lines. GI 50 and TGI for members of the breast cell lines calculated as describe in Methods are listed in decreasing $\mathrm{GI}_{50}$ sensitivity with subtype classification and ER/PR/HER2 status reported by Neve et al. [14] and Spellman et al. (personal communication).

Click here for file

[http://www.biomedcentral.com/content/supplementary/1741-

7015-7-77-S1.PDF]

\section{Additional file 2}

Statistically significant mRNA markers of response to PG-11047 (top 250 genes). Markers generated by correlation of growth inhibition $\left(G_{50}\right)$ sensitivity with expression data of the cell lines reported by Neve et al[14]. Click here for file

[http://www.biomedcentral.com/content/supplementary/17417015-7-77-S2.PDF]

\section{Additional file 3}

Statistically significant genomic markers (BAC clones) of response to PG11047. Markers generated by correlation of growth inhibition $\left(\mathrm{GI}_{50}\right)$ sensitivity with array CGH data of the cell lines reported by Neve et al. [14]. Bold text indicates clones located at or near four of the predictive markers. The chromosomal locations of these four predictive markers are also listed. Click here for file

[http://www.biomedcentral.com/content/supplementary/17417015-7-77-S3.PDF]

\section{Additional file 4}

Statistically significant protein markers of response to PG-11047. Markers generated by correlation of growth inhibition $\left(G_{50}\right)$ sensitivity with Western profile data of the cell lines reported by Neve et al. [14]. Click here for file

[http://www.biomedcentral.com/content/supplementary/17417015-7-77-S4.PDF]

\section{Acknowledgements}

This work was supported by the Director, Office of Science, Office of Biological \& Environmental Research, of the US Department of Energy under contract No. DE-AC02-05CHI I23I, by the National Institutes of Health, National Cancer Institute grants U54 I I 2970, P50 CA 58207 and by a Progen Corporation grant to JWG.

\section{References}

I. Cohen SS: A Guide to the Polyamines. New York: Oxford University Press; 1998.

2. Casero RA Jr, Marton LJ: Targeting polyamine metabolism and function in cancer and other hyperproliferative diseases. Nat Rev Drug Discov 2007, 6(5):373-390.

3. Saunders LR, Verdin E: Ornithine decarboxylase activity in tumour cell lines correlates with sensitivity to cell death induced by histone deacetylase inhibitors. Mol Cancer Ther 2006, 5(I I):2777-2785.

4. Levin VA, Hess KR, Choucair A, Flynn PJ, Jaeckle KA, Kyritsis AP, Yung WK, Prados MD, Bruner JM, Ictech S, et al.: Phase III randomized study of postradiotherapy chemotherapy with combination alpha-difluoromethylornithine-PCV versus $P C V$ for anaplastic gliomas. Clin Cancer Res 2003, 9(3):981-990.

5. Meyskens FL Jr, McLaren CE, Pelot D, Fujikawa-Brooks S, Carpenter PM, Hawk E, Kelloff G, Lawson MJ, Kidao J, McCracken J, et al.: Difluoromethylornithine plus sulindac for the prevention of sporadic colorectal adenomas: a randomized placebo-controlled, double-blind trial. Cancer Prev Res Phila Pa 2008, I(I):32-38.

6. Casero RA Jr, Woster PM: Recent advances in the development of polyamine analogues as antitumour agents. J Med Chem 2009, 52(I 5):455I-4573.

7. Reddy VK, Valasinas A, Sarkar A, Basu HS, Marton LJ, Frydman B: Conformationally restricted analogues of I N, I $2 \mathrm{~N}$-bisethylspermine: synthesis and growth inhibitory effects on human tumor cell lines. J Med Chem 1998, 4 I(24):4723-4732.

8. Hacker A, Marton LJ, Sobolewski M, Casero RA Jr: In vitro and in vivo effects of the conformationally restricted polyamine analogue CGC-I 1047 on small cell and non-small cell lung cancer cells. Cancer Chemother Pharmacol 2008, 63(I):45-53.

9. Perou CM, Sørlie T, Eisen MB, Rijn M van de, Jeffrey SS, Rees CA, Pollack JR, Ross DT, Johnsen H, Akslen LA, et al.: Molecular portraits of human breast tumors. Nature 2000, 406(6797):747-752.

10. Sorlie T, Tibshirani R, Parker J, Hastie T, Marron JS, Nobel A, Deng S, Johnsen H, Pesich R, Geisler S, et al.: Repeated observation of breast tumor subtypes in independent gene expression data sets. Proc Natl Acad Sci USA 2003, I 00( I 4):84| 8-8423.

II. Chin K, DeVries S, Fridlyand J, Spellman PT, Roydasgupta R, Kuo WL, Lapuk A, Neve RM, Qian Z, Ryder T, et al:: Genomic and transcriptional aberrations linked to breast cancer pathophysiologies. Cancer Cell 2006, I0(6):529-54I.

12. Davidson NE, Hahm HA, McCloskey DE, Woster PM, Casero RA Jr: Clinical aspects of cell death in breast cancer: the polyamine pathway as a new target for treatment. Endocr Relat Cancer 1999, 6(I):69-73.

13. Holst CM, Frydman B, Marton LJ, Oredsson SM: Differential polyamine analogue effects in four human breast cancer cell lines. Toxicology 2006, 223( I-2):7|-8I.

14. Neve RM, Chin K, Fridlyand J, Yeh J, Baehner FL, Fevr T, Clark L, Bayani N, Coppe JP, Tong F, et al.: A collection of breast cancer cell lines for the study of functionally distinct cancer subtypes. Cancer Cell 2006, I0(6):5 I5-527. 
15. Nielsen TO, Hsu FD, Jensen K, Cheang M, Karaca G, Hu Z, Hernandez-Boussard T, Livasy C, Cowan D, Dressler L, et al:: Immunohistochemical and clinical characterization of the basal-like subtype of invasive breast carcinoma. Clin Cancer Res 2004, I0(16):5367-5374.

16. Cheang MC, Voduc D, Bajdik C, Leung S, McKinney S, Chia SK, Perou CM, Nielsen TO: Basal-like breast cancer defined by five biomarkers has superior prognostic value than triple-negative phenotype. Clin Cancer Res 2008, I4(5): | 368-I 376.

17. Hennessy BT, Gonzalez-Angulo AM, Stemke-Hale K, Gilcrease MZ, Krishnamurthy S, Lee JS, Fridlyand J, Sahin A, Agarwal R, Joy C, et al. Characterization of a naturally occurring breast cancer subset enriched in epithelial-to-mesenchymal transition and stem cell characteristics. Cancer Res 2009, 69(10):4I I6-4I 24 .

18. NCl/NIH Developmental Therapeutic Program, Human Tumour Cell Line Screen: [http://dtp.nci.nih.gov/branches/btb/ivclsp.html]

19. Monks A, Scudiero D, Skehan P, Shoemaker R, Paull K, Vistica D, Hose C, Langley J, Cronise P, Vaigro-Wolff A, et al.: Feasibility of a high-flux anticancer drug screen using a diverse panel of cultured human tumor cell lines. I Natl Cancer Inst 199|, 83(II):757-766

20. Dolbeare F, Gratzner H, Pallavicini MG, Gray JW: Flow cytometric measurement of total DNA content and incorporated bromodeoxyuridine. Proc Natl Acad Sci USA 1983, 80( I 8):5573-5577.

21. Das D, Nahle Z, Zhang MQ: Adaptively inferring human transcriptional subnetworks. Molecular systems biology 2006, 2:2006-0029.

22. Storey JD, Tibshirani R: Statistical significance for genomewide studies. Proceedings of the National Academy of Sciences of the United States of America 2003, I 00( I 6):9440-9445.

23. Hess KR, Anderson K, Symmans WF, Valero V, Ibrahim N, Mejia JA Booser D, Theriault RL, Buzdar AU, Dempsey PJ, et al.: Pharmacogenomic predictor of sensitivity to preoperative chemotherapy with paclitaxel and fluorouracil, doxorubicin and cyclophosphamide in breast cancer. J Clin Oncol 2006, 24(26):4236-4244.

24. Ignatenko NA, Yerushalmi HF, Pandey R, Kachel KL, Stringer DE, Marton LJ, Gerner EW: Gene expression analysis of HCTII6 colon tumour-derived cells treated with the polyamine analog PG-I I 047. Cancer Genomics Proteomics 2009, 6(3): 16I-175.

25. Myhre L, Alm K, Hegardt C, Staaf J, Jönsson G, Larsson S, Oredsson SM: Different cell cycle kinetic effects of NI, NI I-diethylnorspermine-induced polyamine depletion in four human breast cancer cell lines. Anticancer Drugs 2008, 19(4):359-368.

26. Satriano J, Ishizuka S, Archer DC, Blantz RC, Kelly C): Regulation of intracellular polyamine biosynthesis and transport by NO and cytokines TNF-alpha and IFN-gamma. Am J Physiol 1999 276:C892-899.

27. Macrae M, Neve RM, Rodriguez-Viciana P, Haqq C, Yeh J, Chen C, Gray JW, McCormick F: A conditional feedback loop regulates Ras activity through EphA2. Cancer Cell 2005, 8(2): I I|-| |8.

28. Palacios J, Robles-Frias MJ, Castilla MA, Lopez-Garcia MA, Benftez J: The molecular pathology of herediatary breast cancer. Pathobiology 2008, 75(2):85-94

29. Lu S, Simin K, Khan A, Mercurio AM: Analysis of integrin beta4 expression in human breast cancer: association with basallike tumors and prognostic soignificance. Clin Cancer Res 2008, I 4(4): 1050-1058.

30. Yano M, Hirai K, Naito Z, Yokoyama M, Ishiwata T, Shiraki Y, Inokuchi M, Asano G: Expression of cathepsin B and cystatin C in human breast cancer. Surg Today 200I, 3 I (5):385-389.

31. Padau D, Massague J: Roles of TGFbeta in metastasis. Cell Res 2009, I9(I):89-102.

32. Martin TA, Pereira G, Watkins G, Mansel RE, jiang WG: N-WASP is a putative tumour suppressor in breast cancer cells, in vitro and in vivo and is associated with clinical outcome in patients with breast cancer. Clin Exp Metastasis 2008, 25(2):97-108.

33. Jiang WG, Raz A, Douglas-Jones A, Mansel RE: Expression of autocrine motility factor (AMF) and its receptor, AMFR, in human breast cancer. J Histochem Cytochem 2006, 54(2):23I-24I.

34. Prehoda KE, Scott JA, Mullins RD, Lim WA: Integration of multiple signals through cooperative regulation of the N-WASPArp2/3 complex. Science 2000, 290(5492):80I-806.

35. Kariya Y, Miyazaki K: The basement membrane protein laminin-5 acts as a soluble cell motility factor. Exp Cell Res 2004, 297:508-520.
36. Kojic LD, Joshi B, Lajoie P, Le PU, Cox ME, Turbin DA, Wiseman SM, Nabi IRWH, Raz A: Raft-dependent endocytosis of autocrine motility factor is phosphatidylinositol 3-kinase-dependent in breast carcinoma cells. J Biol Chem 2007, 282(40):29305-293 I3.

37. McCormack SA, Johnson LR: Polyamines and cell migration. J Physiol Pharmacol 200I, 52(3):327-349.

38. Carpenter PM, Wang-Rodriguez J, Chan OT, Wilczynski SP: Laminin 5 expression in metaplastic breast carcinomas. Am J Surg Pathol 2008, 32(3):345-353.

39. Song IS, Tatebe S, Dai W, Kuo MT: Delayed mechanism for induction of gamma-glutamylcysteine synthetase heavy subunit mRNA stability by oxidative stress involving p38 mitogen-activated protein kinase signaling. J Biol Chem 2005, 280(3I):28230-28240.

40. Li Y, Keller DM, Scott JD, Lu H: CK2 phosphorylates SSRPI and inhibits its DNA-binding activity. J Biol Chem 2005, 280(12): | | 869-1| 875 .

4I. Horowitz DS, Lee EJ, Mabon SA, Misteli T: A cyclophilin functions in pre-mRNA splicing. EMBO J 2002, 21 (3):470-480.

42. Reinberg D, Sims RJ: de FACTo nucleosome dynamics. J Biol Chem 2006, 28 I(33):23297-2330I.

43. Stegmeier F, Sowa ME, Nalepa G, Gygi SP, Harper JW, Elledge SJ: The tumour suppressor CYLD regulates entry into mitosis. Proc Natl Acad Sci USA 2007, 104(2I):8869-8874.

44. Eto M, Elliott E, Prickett TD, Brautigan DL: Inhibitor-2 regulates protein phosphatase-I complexed with NimA-related kinase to induce centrosome separation. J Biol Chem 2002, 277(46):440I3-44020.

45. Kovalenko A, Chable-Bessia C, Cantarella G, Israël A, Wallach D, Courtois G: The tumour suppressor CYLD negatively regulates NF-kappaB signalling by deubiquitination. Nature 2003 , 424(6950):80 I-805.

46. Monaco C, Negrini M, Sozzi G, Veronese ML, Vorechovsky I, Godwin AK, Croce CM: Molecular cloning and characterization of LOHI ICR2A, a new gene within a refined minimal region of LOH at I I q23. Genomics 1997, 46(2):2 17-222.

47. Antón IM, Jones GE, Wandosell F, Geha R, Ramesh N: WASP-interacting protein (WIP): working in polymerisation and much more. Trends Cell Biol 2007, I 7(II):555-562.

48. Sathyanarayana UG, Padar A, Huang CX, Suzuki M, Shigematsu $H$, Bekele BN, Gazdar AF: Aberrant promoter methylation and silencing of laminin-5-encoding genes in breast carcinoma. Clin Cancer Res 2003, 9( I 7):6389-6394.

49. Fiaschi T, Marzella R, Veggi D, Marzocchini R, Raugei G, Rocchi M, Ramponi G: Assignment of the human erythrocyte acylphosphatase gene (ACYPI) to chromosome band I4q24.3. Cytogenet Cell Genet 1998, 81:235-236.

50. Barker HE, Smyth GK, Wettenhall J, Ward TA, Bath ML, Lindeman G], Visvader JE: Deaf-I regulates epithelial cell proliferation and side-branching in the mammary gland. BMC Dev Biol 2008, 8:94- 107

5I. Manne U, Gary BD, Oelschlager DK, Weiss HL, Frost AR, Grizzle WE: Altered subcellular localization of suppressin, a novel inhibitor of cell-cycle entry, is an independent prognostic factor in colorectal adenocarcinomas. Clin Cancer Res 200I, 7(I I):3495-3503.

52. Yao H, Ye J: Long chain acyl-CoA synthetase 3-mediated phosphatidylcholine synthesis is required for assembly of very low density lipoproteins in human hepatoma Huh7 cells. J Biol Chem 2008, 283(2):849-854.

\section{Pre-publication history}

The pre-publication history for this paper can be accessed here:

http://www.biomedcentral.com/1741-7015/7/77/prepub 